\title{
SUPERALLOY SCRAP-GENERATION AND RECYCLING ${ }^{1}$
}

\author{
L. R. Curwick ${ }^{2}$, W. A. Petersen ${ }^{3}$, and J. J. deBarbadillo \\ Inco Research \& Development Center, Inc. \\ Sterling Forest, Suffern, NY 10901
}

The domestic availability of chromium and other strategic elements from superalloy and high temperature alloy scrap was assessed. The alloy classes surveyed were investment cast, hardfacing cast, and wrought nickel-and cobaltbase alloys, and wrought nickel-iron-base alloys. Data were collected for 1976 on scrap generatinn, use patterns and production practices. A model was developed which allowed an assessment of the materials flow circuits within the industries which produce these alloys. The types, amounts, sources, secondary products, and ultimate destinations of scrap were determined.

Of the 133.7 thousand metric tons (kt) of scrap generated from these four alloy classes in 1976, about 62\% (83.0 kt) was remelted by the same alloy producing industries; about $25 \%$ (33.7 kt) was downgraded for use in stainless and low alloy sleels; aboul $7 \%(9.0 \mathrm{kt})$ was exported; and about 6\% ( $8.0 \mathrm{kt})$ was lost through disposal or service wastage. The lost material was primarily contaminated oxides for which recovery is currently uneconomic. However, the $42.7 \mathrm{kt}$ of scrap material downgraded or exported in 1976 contained potentially recoverable critical strategic elements. The amount of material lost to the industry in this manner contained $7.2 \mathrm{kt}$ of chromium, $22.5 \mathrm{kt}$ of nickel, $2.7 \mathrm{kt}$ of cobalt, $7.0 \mathrm{kt}$ of iron, and $3.3 \mathrm{kt}$ of other alloying elements.

\footnotetext{
TInformation in this paper was derived from a report preparecl by Inco Research \& Development Center, Inc., Suffern, NY, under Bureau of Mines Contract No. J-0188056. $2_{\mathrm{High}} \mathrm{Temperature} \mathrm{Materials} \mathrm{Section} \mathrm{Manager.}$

${ }^{3}$ Senior Project Manager-Development.

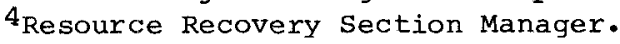




\section{INTRODUCTION}

There is growing concern that non-market factors may affect the price and availability of metals used in high temperature alloys for military and other high technology applications. $\mathrm{Cr}$ is of particular concern because most of the major ore bodies are located in areas outside of the United States which may be subject to political disruption. $\mathrm{Cr}$ is of technological importance and has no substitutes for its most critical applications. The $\mathrm{Cr}$ supply and consumption situation has been recently reviewed in detail(1). Other metals of concern are $\mathrm{Co}, \mathrm{Ni}, \mathrm{W}, \mathrm{Mo}, \mathrm{Cb}$, and $\mathrm{Ta}$. All of these metals are used in substantial quantities in Ni-, Co-, and Ni-Fe-base alloys.

The industries covered in this study were categorized as producers, fabricators, manufacturers, users and recyclers of the alloys covered. The major participants in these industries are high technology companies which are conscious of product quality requirements and which work closely with customers on materials problems.

It is common practice in the alloy melting industry to make maximum use of scrap as a raw material, since scrap metal is usually less expensive than primary metals and sometimes more readily available. Qualitative information on the generation and use of scrap metal by the alloy producing and using industries has been presented $(2,3)$. However, a comprehensive quantitative study has not been conducted. The principal objective of this study was to assess the domestic availability of superalloy and other high temperature alloy scrap. The information that was needed included types, quantities, sources, secondary products, and ultimate destinations of scrap for the alloy classes mentioned previously. The information reported in this paper was generated as part of a broader study, the complete results of which are contained in ref. (4).

\section{PROCEDURES, ASSUMPTIONS AND DATA SOURCES}

Model. It was recognized that it was not possible to gather complete and exact data on scrap generation by all phases of the producing and using industries. Therefore, a production model for these industries was developed which, given available data and reliable estimates of overall industry practices, would allow derivation of the information required to meet the objectives of this study. 
The production model adopted for the study was based on a material balance principle. This model (Figure 1) follows the alloys from the raw materials stage through the primary and finished product stages to obsolescence. The model shows the amount of home and prompt industrial scrap generated in 1976 and predicts the amount of obsolete scrap that will be available at finished product obsolescence 5-10 years in the future. Home scrap is generated by alloy producers during the primary product manufacturing process. Prompt industrial scrap is generated during the finished product manufacturing process. Obsolete scrap is generated from scrapped obsolete equipment and service wastage.

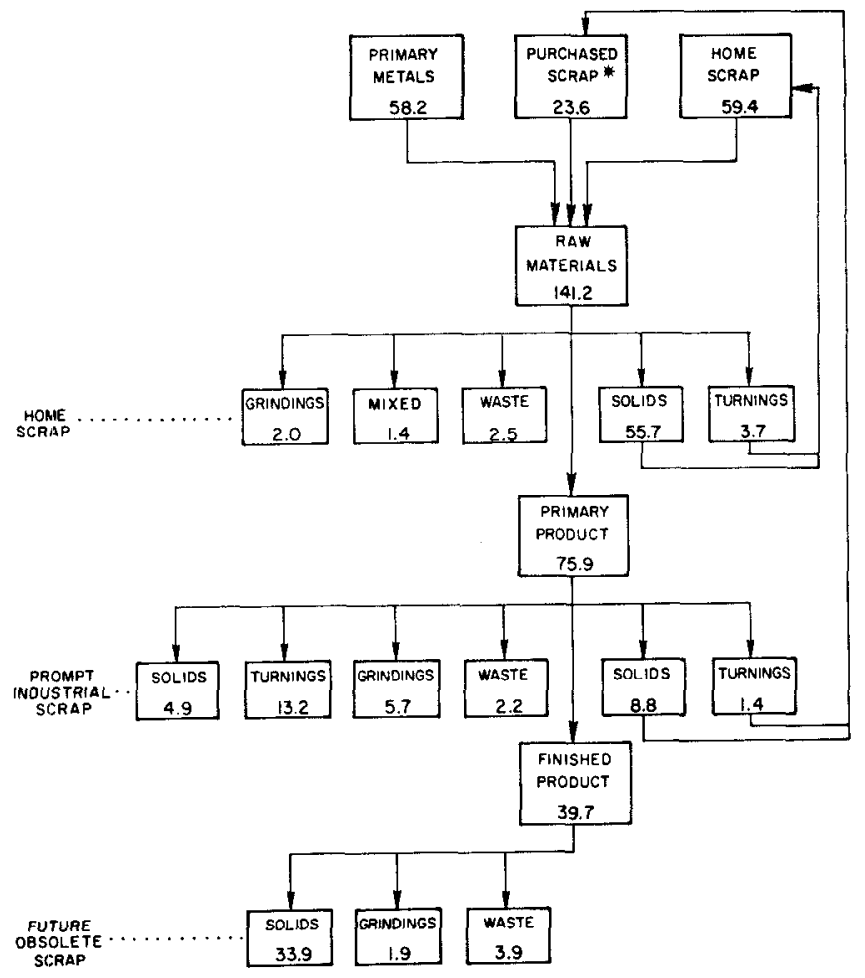

Figure 1: Materials flow diagram for the four alloy classes covered in this study. Numbers indicate quantities for 1976, in thousand metric tons. *Note that purchased scrap component of the melt charge includes $13.4 \mathrm{kt}$ of current obsolete scrap from past production. Not shown is the total quantity of current obsolete scrap available in 1976, $32.2 \mathrm{kt}$. 
Definition of Alloys. Alloys included in this study were the $\mathrm{Cr}$ containing $\mathrm{Ni}-, \mathrm{Co}$ and $\mathrm{Ni}-\mathrm{Fe}$ base alloys. These generic alloys were divided into four broad classes with the alloy composition ranges shown in Table 1. These classifications were carefully selected to encompass products of distinct alloy producing industries and therefore, do not correspond precisely to those used in other industry and government reports. The classifications selected greatly simplified development of the production model and facilitated the understanding of the scrap flow patterns.

Table 1. Nominal composition ranges of the alloy classes.

\section{Alloy Class}

Composition, weight percent

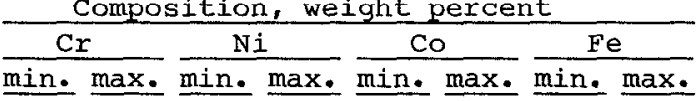

Investment cast

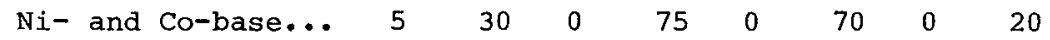

Hardfacing cast

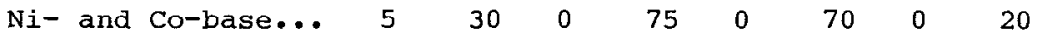

Wrought Ni- and

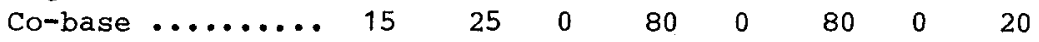

Wrought $\mathrm{Ni}-\mathrm{Fe}-$

base............. $12 \quad 30 \quad 10 \quad 45 \quad 0 \quad 20 \quad 25 \quad 55$

Sources of Information. Data on alloy production, melt charge makeup, scrap generation, and scrap disposition were gathered from open literature and verbal responses to direct industry inquiries. The authors also had access to proprietary purchased surveys and in-house industry related expertise of The International Nickel Company, Inc. Trade association reports, government statistical reports and government sponsored surveys and reports related to $\mathrm{Ni}$ alloy utilization, scrap generation and disposition were available from the literature. Specific references are contained in reference (4).

The most complete set of data on alloy production and distribution existed for 1976. Therefore, this year was chosen as the base year for this study. Alloy production was lower than normal in 1976 but this does not affect the validity of the model or interpretation of the results.

A survey was conducted, by telephone and personal interview, of technical and/or purchasing personnel in 53 organizations involved in producing or using the alloys. 
This was done to obtain data for this report and to varify derived data and conclusions.

Reliability. Since there is no mandatory reporting of this type of information by producers, manufacturers, or scrap processors, all of the data contained in this report are either estimated or derived. There are significant differences in production practices and terminology among various companies and in those reports which are available, there is considerable variation in the alloy and product nomenclature. The reliability of the model and derivations was influenced by all of these factors. Assessments of the results by industry participants indicated that the overall materials balance was accurate although there were differences of opinion regarding the magnitude of individual derived quantities.

Assumptions. The following assumptions were made regarding disposition of prompt industrial and obsolete scrap. They were based on widely accepted industry views where specific data was not available. (1) In the absence of quantitative data from scrap recyclers, it was assumed that only identified clean, solid scrap would be purchased by the alloy producer to make up the purchased scrap portion of the melt charge. (2) Scrap was only recycled within the same alloy class. This was made to simplify the analysis, although it was known that some interchange takes place. (3) Half of the remaining solid prompt industrial and obsolete scrap was exported and half was recycled within the United States as a charge material for iron and steel production. This was substantiated by study responses and inference from Bureau of Mines statistics on related generic alloy classes. (4) Only the highest quality alloy scrap, not fully utilized by U.S. industries, was exported. Therefore, it was assuned that all of the prompt industrial scrap turnings is recycled domestically. (5) Grindings and mixed melt shop scrap were being reprocessed for use in the U.S. steel industry because it was unsuitable for remelting by the superalloy producers.

Information Gaps. The principal information gap in the study was the lack of data on the quantity of prompt industrial and obsolete scrap which is handled by the scrap dealers, reprocessors, and secondary refiners. This is a highly competitive industry and quantitative data was not available from recyclers or industry trade associations. 
clearly, a broadly-based survey of this industry would be useful.

\section{RESULTS AND DISCUSSION}

Primary Product/Home Scrap. An accurate estimate was made of the quantity (Table 2) and average composition (Table 3) of primary production for 1976. In 1976, 75.9 kt of primary product of the four alloy classes covered by this study were produced.

Table 2. Estimated production by alloy class in 1976.

\begin{tabular}{|c|c|c|c|}
\hline \multirow[b]{2}{*}{ Alloy class } & \multicolumn{3}{|c|}{ Quantity, thousand metric tons } \\
\hline & $\begin{array}{l}\text { Raw Materials } \\
\text { Melted } \\
\end{array}$ & $\begin{array}{l}\text { Primary } \\
\text { Product }\end{array}$ & $\begin{array}{l}\text { Finished } \\
\text { Product }\end{array}$ \\
\hline \multicolumn{4}{|l|}{ Investment cast $\mathrm{Ni}-$ and } \\
\hline Co-base............ & 13.2 & 10.6 & 4.2 \\
\hline \multicolumn{4}{|l|}{ Hardfacing cast Ni-and } \\
\hline Co-base............. & 4.7 & 3.7 & 2.2 \\
\hline Wrought Ni- and Co-base. & 81.6 & 40.8 & 22.1 \\
\hline Wrought $\mathrm{Ni}-\mathrm{Fe}$-base. ..... & 41.7 & 20.8 & 11.2 \\
\hline 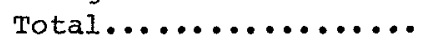 & $\overline{141.2}$ & 75.9 & 39.7 \\
\hline
\end{tabular}

Table 3. Calculated weighted average composition by class.

\begin{tabular}{|c|c|c|c|c|c|}
\hline Alloy class & $\mathrm{Cr}$ & $\mathrm{Ni}$ & $\mathrm{Co}$ & $\mathrm{Fe}$ & others \\
\hline$i-$ ar & & & & & \\
\hline $\begin{array}{l}\text { Co- base............... } \\
\text { lardfacing cast } \mathrm{Ni}-\text { and }\end{array}$ & 13.3 & 63.6 & 7.4 & 1.1 & 14.6 \\
\hline Co-base............ & 24.4 & 8.0 & 54.9 & 0.7 & 12.0 \\
\hline Wrought $\mathrm{Ni}-$ and Co-base.. & 18.2 & 62.5 & 4.8 & 7.0 & 7.5 \\
\hline Wrought Ni-Fe-base....... & 15.0 & 34.1 & 3.5 & 42.1 & 5.3 \\
\hline
\end{tabular}

The alloy producers provided an estimate of their production efficiency. On average, this was found to be 548. Based on this efficiency and the quantity of primary product, it was possible to calculate that $141.2 \mathrm{kt}$ of raw materials were melted by the alloy producers in 1976. Results for each alloy class are given in Table 2. The average mixture of raw materials for melting was 418 (58.2 kt) primary metals, $17 \%(23.6 \mathrm{kt})$ purchased scrap, and 
$42 \%$ ( $59.4 \mathrm{kt}$ ) home scrap. These results for each alloy class are given in Table 4 . In addition, the alloy producers were asked to characterize the scrap material generated from the production cycle. The form and quantity of home scrap generated during the alloy production cycle is shown in Table 5. Disposition of the home scrap is given in Table 6.

Table 4. Melt charge raw materials

\begin{tabular}{|c|c|c|c|c|}
\hline \multirow[b]{2}{*}{ Alloy Class } & \multicolumn{4}{|c|}{ Quantity, thousand metric tons } \\
\hline & $\begin{array}{l}\text { Primary } \\
\text { Metal } \\
\end{array}$ & $\begin{array}{l}\text { Home } \\
\text { Scrap }\end{array}$ & $\begin{array}{c}\text { Purchased } \\
\text { Scrap } \\
\end{array}$ & Total \\
\hline Investment cast & 50 & 11 & 62 & 12 \\
\hline $\begin{array}{l}\text { Ni- and co-base.. } \\
\text { Hardfacing cast }\end{array}$ & 5.9 & 1.1 & 6.2 & 13.2 \\
\hline $\begin{array}{l}\text { Ni- and Co-base.. } \\
\text { Wrought Ni- and }\end{array}$ & 2.9 & 0.4 & 1.4 & 4.7 \\
\hline $\begin{array}{l}\text { Co-base........ } \\
\text { Wrought } \mathrm{N} i-\mathrm{Fe}-\end{array}$ & 32.7 & 38.3 & 10.6 & 81.6 \\
\hline base........... & 16.7 & 19.6 & 5.4 & 41.7 \\
\hline Total............ & 58.2 & 59.4 & 23.6 & 141.2 \\
\hline
\end{tabular}

Table 5. Source, form, and quantity of scrap generated.

$\begin{array}{ll}\frac{\text { Quantity, thousand metric tons }}{\text { Form }} \\ \text { Source } & \text { Solids Turnings Grindings Mixed Waste Total }\end{array}$

\begin{tabular}{|c|c|c|c|c|c|c|}
\hline Home.... & 55.7 & 3.7 & 2.0 & 1.4 & 2.5 & 65.3 \\
\hline Prompt & 13.7 & 14.6 & 5.7 & 0 & 2.2 & 36.2 \\
\hline Current: Obs. 1 & 27.4 & 0 & 1.5 & 0 & 3.3 & 32.2 \\
\hline Total... & 96.8 & 18.3 & 9.2 & 1.4 & 8.0 & 133.7 \\
\hline
\end{tabular}

1Obsolete scrap available in 1976 from production in previous years. 
Table 6. Scrap disposition by source, form, and quantity.

\begin{tabular}{|c|c|c|c|c|c|}
\hline \multirow[b]{3}{*}{ Disposition } & \multicolumn{5}{|c|}{ Quantity, thousand metric tons } \\
\hline & \multirow[b]{2}{*}{ Form } & \multicolumn{2}{|c|}{ Origin } & \multirow[b]{2}{*}{ obsolete } & \multirow[b]{2}{*}{ Total } \\
\hline & & Home & Frompt Ind. & & \\
\hline \multirow[t]{2}{*}{ Remelted..... } & $\mathbf{S}$ & 55.7 & 8.8 & 13.4 & 83.0 \\
\hline & $\mathbf{T}$ & 3.7 & 1.4 & 0 & \\
\hline \multirow[t]{4}{*}{ Downgraded... } & $\mathbf{S}$ & 0 & 2.4 & 7.5 & 33.7 \\
\hline & $\mathbf{T}$ & 0 & 13.2 & 0 & \\
\hline & G & 2.0 & 5.7 & 1.5 & \\
\hline & $M$ & 1.4 & 0 & 0 & \\
\hline Lost..... & $\mathrm{W}$ & 2.5 & 2.2 & 3.3 & 8.0 \\
\hline Exported..... & $\mathbf{s}$ & 0 & 2.5 & 6.5 & 9.0 \\
\hline Total...... & & 65.3 & 36.2 & 32.2 & $\overline{133.7}$ \\
\hline
\end{tabular}

S=Solids, $\mathrm{T}=$ Turnings, $\mathrm{G}=\mathrm{Grindings,} \mathrm{M}=$ Mixed, $\mathrm{W}=$ Waste.

Finished Product/Prompt Industrial Scrap. Through discussions with finished product manufacturers and industry experts, it was determined that the overall average efficiency of utilization of primary product in the manufacture of finished products was about $52 \%(28 \%$ of the raw materials melted). Thus, of the $75.9 \mathrm{kt}$ of primary product of the four alloy classes studied, it was estimated that $39.7 \mathrm{kt}$ was contained in finished products (i.e., heat exchangers, gas turbine engines, chemical process equipment) in 1976 (Table 2) and $36.2 \mathrm{kt}$ of prompt industrial scrap was generated. The form and disposition of this prompt industrial scrap is given in Tables 5 and 6 .

Obsolete Scrap. Discussions were held with end users, scrap dealers, and industry experts to determine the average finished product lifetime and practices for scrapping obsolete equipment. It was estimated that the average lifetime for components made from cast $\mathrm{Ni}$ - and Co-base alloys was 5 years. The average lifetime was 10 years for those products made from wrought alloys. An estimate was then made of the quantity of obsolete scrap which would be available in 1976. This quantity was derived from primary production data from previous years(4). The amount of service wastage and the character, quantity, and disposition of obsolete scrap generated obsolete equipment was removed from service and scrapped in 1976 was also estimated. Based on these estimates, $32.2 \mathrm{kt}$ of current obsolete scrap of cast and wrought superalloys and other $\mathrm{Ni}-, \mathrm{Co}-$, and $\mathrm{Ni}-\mathrm{F}^{\prime} \mathrm{e}-$ base alloys, was generated in 1976. Note this is lower than the $39.7 \mathrm{kt}$ of finished products (future obsolete scrap) 
manufactured from these alloys in that year. The form and disposition of obsolete scrap generated in 1976 is given in Tables 5 ana 6 .

Overall Recycling Efficiency. Of the $133.7 \mathrm{kt}$ of scrap generated in 1976 from the four alloy classes considered, approximately $62 \%(83.0 \mathrm{kt})$ was remelted by the same alloy producing industries, $258(33.7 \mathrm{kt}$ ) was downgraded into stainless steel and low alloy steels, $78(9.0 \mathrm{kt})$ was exported, and $6 \%(8.0 \mathrm{kt})$ was lost through disposal or service wastage. The export estimate may be compared with The U.S. Bureau of Mines estimate for net exports in 1976, $12.3 \mathrm{kt}(5)$. It should be noted that the latter estimate was obtained from a somewhat broader alloy base. The lost material was primarily contaminated oxides for which recovery was uneconomic. However, the $42.7 \mathrm{kt}$ of scrap material estimated to be downgraded or exported in 1976 contained potentially recoverable metals.

Availability of Chromium and other Strategic Elements. The quantities of $\mathrm{Cr}, \mathrm{Ni}, \mathrm{Co}, \mathrm{Fe}$, and other elements contained in the melt charge raw materials, primary and finished products and the four scrap classifications are given in Table 7. A significant amount of $\mathrm{Cr}(7.2 \mathrm{kt})$ was contained in superalloy and high temperature alloy scrap downgraded or exported in 1976. In addition, this downgraded or exported scrap contained $22.5 \mathrm{kt}$ of $\mathrm{Ni}, 2.7 \mathrm{kt}$ of $\mathrm{Co}$, $7.0 \mathrm{kt}$ of $\mathrm{Fe}$ and $3.3 \mathrm{kt}$ of other elements. Recovery of this $\mathrm{Cr}$ and other strategic metals would provide a significant quantity of the primary metal needs of these alloy producing industries.

Table 7. Quantity of elements contained in products and scrap in 1976.

Quantity, thousand metric tons

\begin{tabular}{|c|c|c|c|c|c|c|}
\hline \multirow[b]{2}{*}{ Material/Product } & \multicolumn{5}{|c|}{ Element } & \multirow[b]{2}{*}{ Total } \\
\hline & $\mathrm{Cr}$ & $\mathrm{Ni}$ & $\mathrm{Co}$ & $\mathrm{Fe}$ & Others & \\
\hline Raw material ${ }^{1}$ & 24.1 & 74.0 & 8.9 & 23.4 & 10.8 & 141.2 \\
\hline Primary metals & 9.9 & 30.1 & 4.3 & 9.3 & 4.6 & 58.2 \\
\hline Primary product & 12.9 & 39.6 & 5.4 & 11.8 & 6.2 & 75.9 \\
\hline Finished product & 6.8 & 20.5 & 3.0 & 6.3 & 3.1 & 39.7 \\
\hline Remelted scrap & 15.4 & 43.8 & 4.7 & 14.1 & 5.0 & 83.0 \\
\hline Downgraded scrap & 5.7 & 17.6 & 2.3 & 5.5 & 2.6 & 33.7 \\
\hline Lost scrap & 1.4 & 3.7 & 1.1 & 1.0 & 0.8 & 8.0 \\
\hline Exported scrap & 1.5 & 4.9 & 0.4 & 1.5 & 0.7 & 9.0 \\
\hline
\end{tabular}

${ }^{1}$ Includes primary metals, home scrap and purchased scrap. 
1. A production model, which defines the flow of materials from raw materials to obsolete scrap, has been established and verified for four related alloy classes produced by the superalloy and high temperature alloy industries.

2. Scrap has been identified according to quantity, alloy class, physical form, grade or quality, origin and destination.

3. The total quantity of scrap generated in the production and use of these alloys in 1976 was $133.7 \mathrm{kt}$ containing $24.0 \mathrm{kt}$ of $\mathrm{Cr}$. Approximately $42.7 \mathrm{kt}$ of scrap containing about $7.2 \mathrm{kt}$ of $\mathrm{Cr}$ was downgraded or exported. About $8.0 \mathrm{kt}$ of scrap containing $1.4 \mathrm{kt}$ of $\mathrm{Cr}$ was physically lost or considered as waste which was too contaminated to economically recover.

4. The production model developed in this study could provide the basis for a more intensive survey which would define specific aspects of materials flow within the industry with greater precision.

\section{REFERENCES}

1. Summary Report on Air Force Chromium Workshop. Metals and Ceramics Division, Air Force Materials Laboratory, Air Force Systems Command, Wright-Patterson Air Force Base, OH, 45433, May 1975.

2. J. R. Boyle. Manufacturing Methods for strategic Materials Reclamation, Sixth Interim Technical Report, Pratt \& Whitney Aircraft, Report AFML-IR-162-4-VI, AFML Contract F33615-74-C-5019, September 30, 1975, $56 \mathrm{pp}$.

3. R. S. Cremisio and L. M. Wasserman. Superalloy Scrap Processing and Trace Element Considerations. Proceedings of the 1977 Vacuum Metallurgy Conference. Edited by R. C. Krutenat. Science Press, Princeton, NJ, June 20-22, 1977, p. 353.

4. L. R. Curwick, W. A. Petersen and H. V. Makar: Availability of Critical scrap Metals Containing Chromium in the United States-Part I-Superalloys and Cast Heat and Corrosion Resistant Alloys. U.S. Bureau of Mines Information Circular, to be published in 1980.

5. J. D. Corrick, et. al. Nickel, Mineral Industry Surveys. December 1958-1978. U.S. Department of Interior, Bureau of Mines, Washington, DC 20241. 